\title{
Trend Analysis of Observed Precipitation, Temperature and Streamflow for Hadejia - Nguru Wetlands Catchment, Nigeria
}

\section{Salisu Dan'azumi}

Bayero University Kano

Usman Abdullahi Ibrahim ( $\nabla$ uaibrahim@unimaid.edu.ng )

University of Maiduguri https://orcid.org/0000-0003-1820-8929

\section{Research Article}

Keywords: precipitation, temperature, streamflow, trend analysis, Mann-Kendall

Posted Date: July 13th, 2021

DOI: https://doi.org/10.21203/rs.3.rs-650459/v1

License: (c) (i) This work is licensed under a Creative Commons Attribution 4.0 International License.

Read Full License 


\title{
Trend Analysis of Observed Precipitation, Temperature and Streamflow for Hadejia - Nguru Wetlands Catchment, Nigeria
}

\author{
S. Dan' azumi $^{1}$ and U. A. Ibrahim ${ }^{2 *}$ \\ $\left({ }^{1}\right.$ Department of Civil Engineering, Bayero University Kano \\ ${ }^{2}$ Department of Civil and Water Resources Engineering, University of Maiduguri) \\ *Corresponding author's name: Usman Abdullahi Ibrahim \\ Email address: uaibrahim@unimaid.edu.ng
}

\begin{abstract}
This study investigated trends in hydro-climate data (precipitation, maximum/minimum temperatures, and streamflow) for the period 1980-2016 in a semi-arid Hadejia-Nguru Wetlands (HNWs) catchment, Nigeria. Four meteorological stations (Bauchi, Hadejia, Kano and Nguru) and three streamflow gauge stations (Gashua, Hadejia and Katagum on Rivers Yobe, Hadejia and Jama'are respectively) covers the HNWs catchment. Anderson-Darling and Shapiro-Wilk normality tests were applied on the monthly hydro-climate data series to determine their class of distribution. A non-parametric Pettit's test for homogeneity was employed to detect change points in the data series. An absolute homogenization method using RHtestsV4 software was applied to homogenize and (as needed) pre-whitened the data series. Trend analysis was carried out using modified Mann-Kendall trend test (trend free pre-whitening approach), while Sen's slope was used to estimate the magnitude of the changes. Results of the study revealed that there was an increasing positive trends at all the stations for monthly minimum, average annual minimum, average annual maximum, and annual average temperature data series. While monthly maximum temperature series of Bauchi and Kano stations indicated the presence of an increasing trend with magnitude $0.0035^{\circ} \mathrm{C}$ and $0.0019^{\circ} \mathrm{C}$; and no trend was detected for Hadejia and Nguru stations. For monthly precipitation, no trends was detected at all stations. However, an increasing trend was detected at Bauchi, Hadejia and Nguru stations for mean annual precipitation with magnitude $7.7960 \mathrm{~mm} / \mathrm{yr}, 8.1766 \mathrm{~mm} / \mathrm{yr}$ and $5.7214 \mathrm{~mm} / \mathrm{yr}$ respectively. A decreasing trend was detected for monthly and annual streamflow series at Hadejia gauge station with magnitude $-0.0115 \mathrm{~m}^{3} / \mathrm{s} / \mathrm{month}$ and $-3.7037 \mathrm{~m}^{3} / \mathrm{s} /$ year respectively; and no trend was detected for monthly and annual streamflow series at Gashua and Katagum gauge stations. The trend analysis may be helpful to water resources managers for planning and management of water resources in the HNWs catchment and the Hadejia Jama'are Komadugu Yobe Basin at large.
\end{abstract}

Keywords: precipitation, temperature, streamflow, trend analysis, Mann-Kendall

\section{Introduction}

Rapid population growth and industrial activities have resulted in the rise of average temperature of the earth leading to global warming over many regions around the globe (Ali et al., 2019). Precipitation and streamflow conditions are influenced by energy exchange between the sun, earth and the atmosphere (Ayeni et al., 2015; Umar et al., 2018). The Intergovernmental Panel on Climate Change (IPCC) in its fifth assessment report gave detailed description based on scientific findings of the physical driving forces of climate change and the potential threats likely to be faced in the future (IPCC, 2013). The report indicated that mean annual global air temperature for the period 1880-2012 had a significant upward trend notably from 1979 to 2012 with a $0.25-0.27^{0} \mathrm{C}$ increment per decade (IPCC, 2013). 
There is no doubt climate change and global warming represent a potential effect on the hydrologic cycle (Chattopadhyay et al., 2017; Ali et al., 2019; Kocsis et al., 2020). This was observed through increasing temperature, thereby altering precipitation patterns. Precipitation is one of the essential components of hydrologic cycle (Chow et al., 1988). The altered precipitation trends have direct impacts on streamflow (Chow et al., 1988; Aich et al., 2014; Kocsis et al., 2020). Streamflows are also found to be very sensitive to changes in precipitation patterns (Ezemonye et al., 2016; Okafor and Ogbu, 2018; Umar et al., 2018). The construction of hydraulic structures, such as dams, barrages, and large weirs can also cause streamflow reduction (Umar and Ankidawa, 2016; Umar et al., 2018). Changes in hydrologic cycle may in turn affect the availability and quality of water resources, and the sustainability of water management, particularly in dry regions (Aich et al., 2014; Ahmad et al., 2015; Kocsis et al., 2020). Thus, it is very important to evaluate the trends in precipitation, temperature and streamflow for sustainable development of water resources and at the same time maintaining adequate environmental flows releases downstream of any hydraulic structure (Goes, 2001; Olalekan et al., 2014).

Several authors reported that trend assessment of precipitation, temperature and streamflow is an important study to make long-term water resources management plans (Chattopadhyay and Edwards, 2016; Chen et al., 2016; Chattopadhyay et al., 2017; Ali et al., 2019). In this regard, a review of the literature revealed that several studies are conducted to understand the changing characteristics of streamflow using precipitation and temperature data around the world, including Nigeria (Ezemonye et al., 2016; Okafor and Ogbu, 2018; Umar et al., 2018).

There are quite a number of statistical test methods used for trend detection in hydrological and hydro-climatic time series (Yue et al., 2002; Hamed, 2008). These statistical test methods are classified as parametric and non-parametric tests (Hamed, 2008). Parametric tests, although more powerful, require data to be independent and normally distributed, which is rarely true for hydrological time series data (Hamed, 2008; Ahmad et al., 2015; Kocsis et al., 2020). Parametric tests are more sensitive to outliers. On the other hand, non-parametric tests are not affected by the actual distribution of the data and are less sensitive to outliers (Hamed, 2008; Ahmad et al., 2015; Kocsis et al., 2020). A common requirement of both parametric and non-parametric trend tests is that the data be independent (free from serial correlation). The effect of serial correlation can be dealt with either by eliminating serial correlation from the data before applying trend tests (prewhitening), or by adjusting the original trend test to account for serial correlation (Yue et al., 2002; Hamed, 2008; Kocsis et al., 2020).

One of the most common and widely used non-parametric test by researchers in studying hydrologic time series is the Mann-Kendall (MK) trend test (Hamed, 2008; Ahmad et al., 2015; Kocsis et al., 2020). However, an observable weakness of the MK test is that, serial correlation as very often seen in the hydro-climate data is not accounted for (Hamed and Rao, 1998; Yue et al., 2002; Yue and Wang, 2004). Studies have shown that if autocorrelation is not considered, the existence of positive autocorrelation will overestimate the magnitude of both positive and negative trends, likewise negative autocorrelation will underestimate the magnitude of both positive and negative trends (Hamed and Rao, 1998; Yue et al., 2002). A modified MK test with trend-free pre-whitening and variance correction were proposed and applied in an attempt to eliminate the impact of serial correlation (Hamed and Rao, 1998; Yue et al., 2002; Yue and Wang, 2004).

The aim of this study is to investigate the possible trends and variations in mean precipitation, average maximum and minimum temperatures, and mean streamflow of Hadejia-Nguru Wetlands catchment for the period (1980-2016). This was carried out by analyzing monthly and annual time series through Modified Mann Kendall (MMK) with trend-free pre-whitening test using R-Studio. 
The Hadejia-Nguru Wetlands catchment lies between Bauchi, Hadejia, Kano and Nguru meteorological stations; and Gashua, Hadejia and Katagum streamflow gauge stations on Rivers Yobe, Hadejia and Jama'are respectively. The results of the analysis may serve as input or source of reference information for decision-making and planning processes to mitigate negative impacts of climate change.

\section{Materials and Methods}

\subsection{Study Area and Datasets}

The Hadejia-Nguru Wetlands (Figure 1) is located at $12^{0} 15^{\prime} \sim 13^{0} 00^{\prime} \mathrm{N}$ and $10^{0} 00^{\prime} \sim 11^{0} 00^{\prime} \mathrm{E}$ in semi-arid region of Northern Nigeria between the towns of Hadejia and Nguru. It had an approximate surface area of about $3,500 \mathrm{~km}^{2}$ (Okali and Bdliya, 1998). The catchment's mean precipitation and average air temperature from 1980 to 2016 ranges between $500 \mathrm{~mm}$ to $600 \mathrm{~mm}$; and $12^{\circ} \mathrm{C}$ during Harmattan season (cold) to about $40^{\circ} \mathrm{C}$ during the hot season respectively, with an annual average evaporation around $3000 \mathrm{~mm}$ (NIMET, 2017). The flood-plain complex comprised seasonally flooded lands and dry uplands. The hydrology of the area is described by a peak runoff flow occurring in August and September during which the banks overflow and the area inundated (Umar and Ankidawa, 2016).

HNWs is on the list of Ramsar wetlands of international importance due to its fundamental ecological functions, socioeconomic value and presence of protected area; it supports at least 250 species of flowering plants, over 136 types of aquatic flora and fauna and more than 103 species of fishes and 377 species of birds (Ayeni et al., 2019). However, some of the wildlife resources are going into extinction as a result of water reduction, climate change, bio-invasion and inadequate monitoring and protection of the resources. It also support a population of about 1.5 million people including farmers, herders, fishermen who primarily depend on the ecosystem for their livelihood (Olalekan et al., 2014).

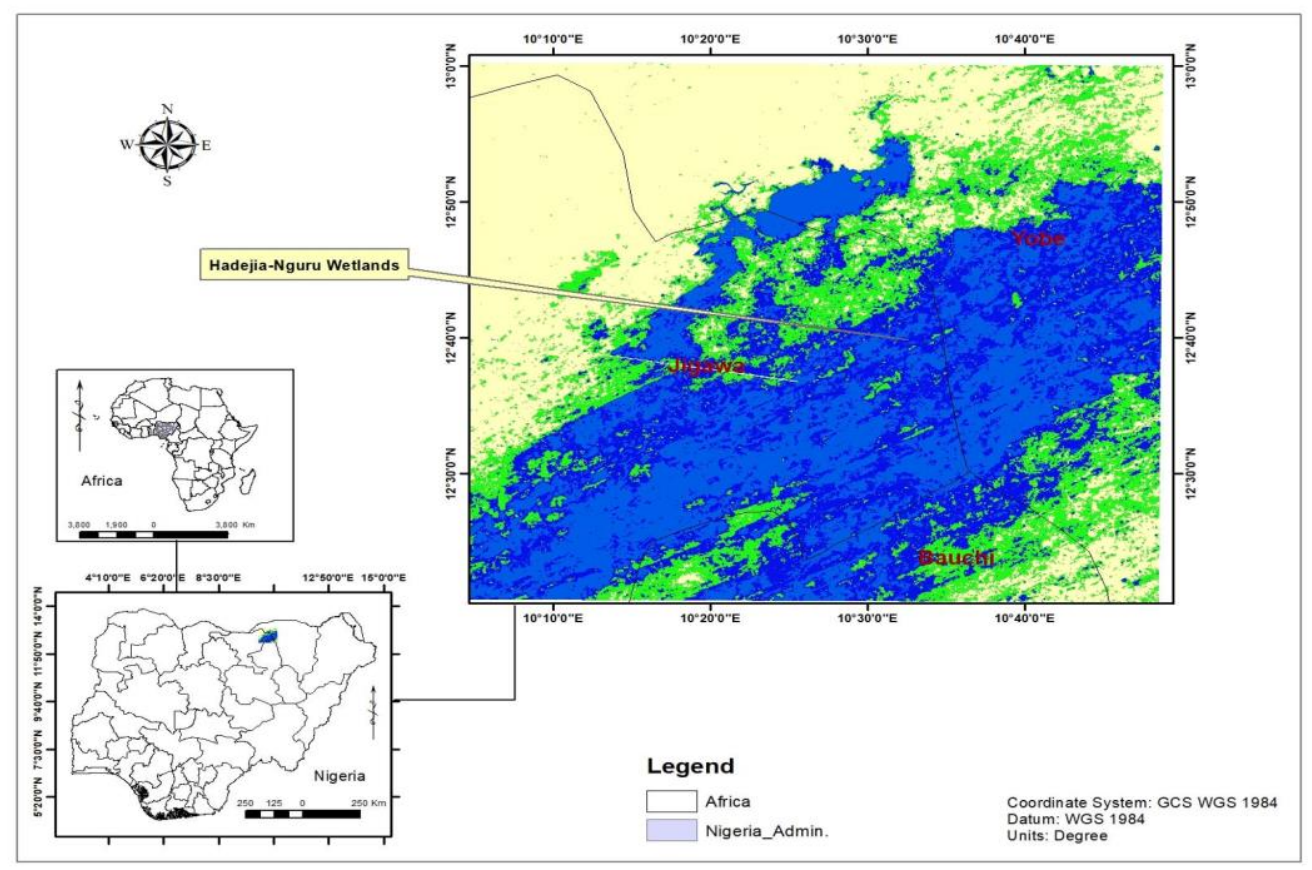

Figure 1: Location of Hadejia-Nguru Wetlands, Nigeria 
Monthly precipitation, maximum and minimum temperatures observation data of Bauchi, Hadejia, Kano and Nguru stations (1980 - 2016) of the Nigerian Meteorological Agency (NIMET) were obtained from Hadejia Jama'are Komadugu Yobe Basin - TrustFund (HJKYB-TF), Damaturu. The meteorological stations were located in and near surroundings of the HNWs. Similarly, monthly observed streamflow at Gashua, Hadejia and Katagum gauge stations on Rivers Yobe, Hadejia and Jama'are respectively (covering HNWs) for the period of $1980-2016$ were also provided by HJKYB-TF. Figure 2 presents positions of the three gauge stations.

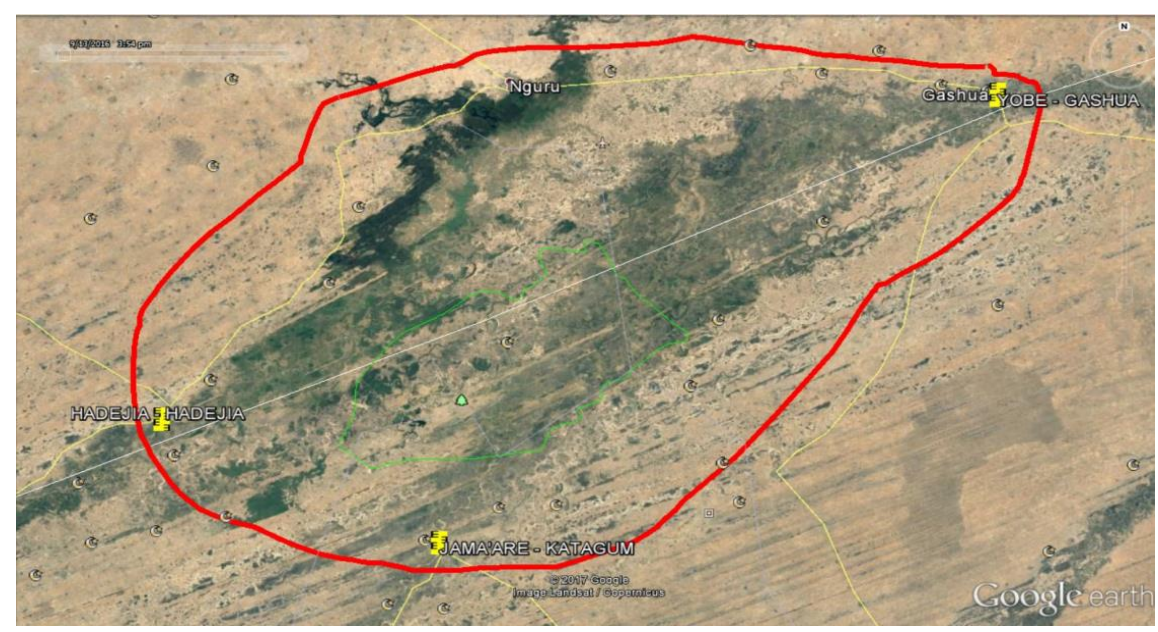

Figure 2: Position of Gashua, Hadejia and Katagum gauge stations

Many researchers have used varying time steps in analyzing trends for different variables (Burn and Elnur, 2002; Kumar et al., 2009; Partal, 2010; Ahmad et al., 2015; Kocsis et al., 2020). It was suggested therefore, that the same length of records should be used when analyzing trends of different variables to avoid misleading conclusions (Drápela and Drápelová, 2011; Chen et al., 2016; Ali et al., 2019). Therefore, precipitation, temperatures and streamflow of the same record length of 37 years for the period 1980-2016 would be adequate for the trend analysis in this study.

\subsection{Pre-processing of Data}

The 37 years monthly hydro-climatic time series were first tested for normality using R statistical software to determine which type of test is applicable; parametric or non-parametric. The Anderson-Darling and Shapiro-Wilk normality tests were used for this study. After normality test, and in consistent with World Meteorological Organization (WMO, 2011) guidelines, the data series were subsequently tested for homogeneity (to detect change points in the time series) and serial correlation.

There are various methods used in detecting inhomogeneity of a data series. For this study, a nonparametric homogeneity test; Pettit's test was used. The approach was introduced by Pettitt (1979), and commonly applied to detect a single change-point in hydrological or climate series with continuous data. The test was used because it gives information about the location of the shift (probable change point). The test statistic is defined as;

$U_{y}=2 \sum_{i=1}^{y} r_{i}-y(n+1), y=1,2, \ldots, n$

The break is detected near the year $y$ given that;

$U_{y}=\max _{1 \leq y \leq n}\left|U_{y}\right|$ 
Where; $n$ is the data set length, $r_{i}$ is the rank of the years $y_{i}$ and $U_{y}$ is the test's critical value.

For homogeneity test, the null hypothesis states that at $95 \%$ confidence level, a data series is homogenous between two given times if p-values are greater than 0.05 . If, however inhomogeneity is detected, the data series are adjusted before further analysis; this adjustments is called Homogenization. Several homogenization methodologies were developed that allow to eliminate or reduce as much as possible these unwanted alterations. The methodologies were further classified under two broad categories; absolute (in which series are tested separately) and relative (in which discontinuities are detected by comparison to applicable reference stations). Homogenization in this study followed an absolute method using RHtestsV4 software.

Serial correlation (or autocorrelation) is when observations of the error term are uncorrelated with each other in a data series (Wang et al., 2015). Relevant studies highlighted the need to check for autocorrelation in a data series prior to trend analysis (Drápela and Drápelová, 2011; Droogers et al., 2012; Gocic and Trajkovic, 2013; Shiru et al., 2018; Umar et al., 2018; Ali et al., 2019). Because the presence of autocorrelation may lead to incorrect estimation of trend or disproportionate rejection of the null hypothesis of no trend, whereas the null hypothesis is actually true (Yue et al., 2002). The hydro-climatic data passing the homogeneity test were next examined for presence of autocorrelation, and if present, correct it before proceeding to trend analysis. The first-order autocorrelation coefficient, $r_{1}$ at $95 \%$ confidence interval using a two-tailed test was calculated from Equation (3);

$r_{1}=\frac{\frac{1}{n-1} \sum_{i=1}^{n-1}\left(x_{i}-\bar{X}\right)\left(x_{i+1}-\bar{X}\right)}{\frac{1}{n} \sum_{i=1}^{n}\left(x_{i}-\bar{X}\right)^{2}}$

If $\frac{-1-1.96 \sqrt{n-2}}{n-1} \leq r_{1} \leq \frac{-1+1.96 \sqrt{n-2}}{n-1}$, then the data series are considered to be serial-independent at $5 \%$ significant level and free from the first-order autocorrelation AR (1). Elsewhere, the data series are considered serially correlated and requires correction (pre-whitening) before further analysis.

Several remedies exists for autocorrelation, the Trend-Free Pre-Whitening (TFPW) approach introduced by Yue et al. (2002) and embedded in the Modified Mann Kendall test R-package was used for this study.

\subsection{Trend Detection and Characterization}

Several studies supported the use of non-parametric methods of trend detection, noting that in-situ hydro-climatic data are often distinctly non-normal with positive skewness (Sonali and Kumar, 2013; Gocic and Trajkovic, 2013; Ahmad et al., 2015; Chattopadhyay and Edwards, 2016; Kocsis et al., 2020).

The non-parametric Mann-Kendall test (Mann, 1945; Kendall, 1975) was adopted for this study. The Mann-Kendall test is based on a rank correlation test of the observed values and their order in time. The Mann-Kendall test statistics $S$ of a series $x$ is given by Equation 4;

$S=\sum_{k=1}^{n=1} \sum_{j=k+1}^{n} \operatorname{sgn}\left(x_{j}-x_{k}\right)$

Where;

$\operatorname{sgn}$ is the signum function defined as;

$\operatorname{sgn}\left(x_{j}-x_{k}\right)=\left\{\begin{array}{l}+1 \text { if }\left(x_{j}-x_{k}\right)>0 \\ 0 \text { if }\left(x_{j}-x_{k}\right)=0 \\ -1 \text { if }\left(x_{j}-x_{k}\right)<0\end{array}\right.$

$x_{j}$ and $x_{k}=$ data points at time $j$ and $k$ respectively

$n=$ number of observations 
For independent and randomly ordered data for large $n$, the $S$ statistics approximate a normal distribution with mean $E(S)=0$ and a variance, $\operatorname{Var}(S)=n(n-1)(2 n+5) / 18$ (Osuch and Wawrzyniak, 2016).

The significance of the trend is tested by comparison of the standardised test statistics, $Z$, with the standard normal cumulative distribution at a selected significance level. The standard test statistics $Z$ is computed as;

$Z=\left\{\begin{array}{c}\frac{S-1}{\sqrt{\operatorname{VAR}(S)}} \text { if } S>0 \\ 0 \quad \text { if } S=0 \\ \frac{S+1}{\sqrt{\operatorname{VAR}(S)}} \text { if } S<0\end{array}\right.$

Positive value of $Z$ statistics indicate an increasing trend, while negative $Z$ value indicate a decreasing trend. The trend is statistically significant at 0.05 significance level when the absolute value of $Z$ is greater than 1.96 .

If autocorrelation exist in a data series, a modified Mann Kendall test based on Yue et al. (2002) approach is applied to avoid the above uncertainty. A pre-whitened series $x_{i}^{*}$ is created from Equation 7;

$x_{i}^{*}=x_{i+1}-r_{1} x_{1}$

Then, the original Mann-Kendall test is applied to the pre-whitened series to assess the trend.

The Theil-Sen's slope estimator, a non-parametric method to quantify trends (or magnitude) in a time series was used to for this study. The Sen's slope estimator for monotonic and linear trend is expressed by the linear mode $f(t)$ as;

$f(t)=Q_{t}+B$

Where;

$f(t)=$ linear model

$Q_{t}=$ the slope

$B=$ constant

The slope $Q$ between any two values of a time series $x$ can be derived from;

$Q_{i}=\frac{x_{j}-x_{k}}{k-j}, k \neq j, i=1,2, \ldots, N$

$x_{j}$ and $x_{k}$ represent data values at time $j$ and $k$ respectively.

If there are $n$ values of $x_{j}$ in the time series we get as many as $N=n(n-1) / 2$ slope estimates of $Q_{i}$. The $N$ values of $Q_{i}$ are ranked from the smallest to the largest and the median of these $N$ values of $Q_{i}$ is the overall Sen's slope estimator $Q$ computed as;

$Q=\left\{\begin{array}{cc}Q_{(N+1) / 2} & \text { if } N \text { is odd } \\ \frac{1}{2}\left(Q_{N / 2}+Q_{(N+2) / 2}\right) & \text { if } N \text { is even }\end{array}\right.$

In trend test, the null $\left(\mathrm{H}_{0}\right)$ and alternative hypotheses $(\mathrm{Ha})$ are equal to the nonexistence and existence of a trend in the observational data series, respectively. Existence of a trend with positive p-values indicates increasing, while negative values indicate decreasing trends in the data series. The p-value was set at a significance level $(\alpha)$ of 0.05 ; implying that any station statistics that produces a $\mathrm{p}$-value less than the set significance level, will lead to the rejection of $\mathrm{H}_{0}$ and that a trend exists in the data series. On the other hand, where the p-value obtained was more than the level of significance $(\alpha)$, then, the $\mathrm{H}_{0}$ of no trend is accepted. 


\section{Results and Discussion}

\subsection{Normality Test}

The normality test conducted on the monthly precipitation, temperature (maximum and minimum) and streamflow series $(1980$ - 2016) indicates that all the data series does not exhibit Gaussian distribution when the Anderson-Darling and Shapiro-Wilk normality test was applied. Tables 1, 2 and 3 illustrate the test results.

Table 1: Anderson-Darling Normality Test for Monthly Precipitation and Temperature

\begin{tabular}{|l|l|l|l|l|l|l|}
\hline \multirow{2}{*}{ Weather station } & \multicolumn{2}{|l|}{ Maximum Temperature } & \multicolumn{2}{l|}{ Minimum Temperature } & \multicolumn{2}{l|}{ Precipitation } \\
\cline { 2 - 8 } & $\mathrm{A}^{2}$ & $\mathrm{p}$-value & $\mathrm{A}^{2}$ & $\mathrm{p}$-value & $\mathrm{A}^{2}$ & $\mathrm{p}$-value \\
\hline Bauchi & 0.963 & 0.015 & 6.796 & $<2.2 \mathrm{e}-16$ & 31.977 & $<2.2 \mathrm{e}-16$ \\
\hline Hadejia & 1.372 & 0.001 & 10.549 & $<2.2 \mathrm{e}-16$ & 50.050 & $<2.2 \mathrm{e}-16$ \\
\hline Kano & 1.897 & $7.59 \mathrm{e}-05$ & 8.590 & $<2.2 \mathrm{e}-16$ & 39.761 & $<2.2 \mathrm{e}-16$ \\
\hline Nguru & 1.122 & 0.006 & 10.880 & $<2.2 \mathrm{e}-16$ & 54.221 & $<2.2 \mathrm{e}-16$ \\
\hline
\end{tabular}

Table 2: Shapiro-Wilk Normality Test for Monthly Precipitation and Temperature

\begin{tabular}{|l|l|l|l|l|l|l|}
\hline \multirow{2}{*}{ Weather station } & \multicolumn{3}{|l|}{ Maximum Temperature } & \multicolumn{2}{l|}{ Minimum Temperature } & \multicolumn{2}{l|}{ Precipitation } \\
\cline { 2 - 8 } & $\mathrm{W}$ & $\mathrm{p}$-value & W & p-value & W & p-value \\
\hline Bauchi & 0.989 & 0.0031 & 0.9666 & $1.63 \mathrm{e}-08$ & 0.8153 & $<2.2 \mathrm{e}-16$ \\
\hline Hadejia & 0.989 & 0.0039 & 0.8425 & $<2.2 \mathrm{e}-16$ & 0.7256 & $<2.2 \mathrm{e}-16$ \\
\hline Kano & 0.986 & 0.0003 & 0.9553 & $2.515 \mathrm{e}-10$ & 0.7642 & $<2.2 \mathrm{e}-16$ \\
\hline Nguru & 0.991 & 0.0062 & 0.9428 & $4.978 \mathrm{e}-12$ & 0.7001 & $<2.2 \mathrm{e}-16$ \\
\hline
\end{tabular}

Table 3: Anderson-Darling and Shapiro-Wilk Normality Tests for Monthly Streamflow

\begin{tabular}{|l|l|l|l|l|}
\hline \multirow{2}{*}{ Gauge station } & \multicolumn{2}{|l|}{ Anderson-Darling } & \multicolumn{2}{l|}{ Shapiro-Wilk } \\
\cline { 2 - 5 } & $\mathrm{A}^{2}$ & $\mathrm{p}$-value & $\mathrm{W}$ & $\mathrm{p}$-value \\
\hline Gashua & 63.99 & $<2.2 \mathrm{e}-16$ & 0.675 & $<2.2 \mathrm{e}-16$ \\
\hline Hadejia & 34.22 & $<2.2 \mathrm{e}-16$ & 0.747 & $<2.2 \mathrm{e}-16$ \\
\hline Katagum & 70.46 & $<2.2 \mathrm{e}-16$ & 0.602 & $<2.2 \mathrm{e}-16$ \\
\hline
\end{tabular}

The null hypothesis $\mathrm{H}_{0}$ of the Anderson-Darling and Shapiro-Wilk tests states that a sample belongs to a normal distribution if p-values are greater than alpha, $\alpha$ at 0.05 significance level. From Tables 1, 2 and 3, the null hypothesis of the Anderson-Darling and Shapiro-Wilk test is rejected and the alternative accepted for all the data series. This is because $\mathrm{p}$-values are less than $\alpha$. Thus, a non-parametric test approach is therefore suitable to analyse these data series.

\subsection{Homogeneity Test}

Homogeneity implies that the data in the series are similar and hence have no breaks over time. The null hypothesis states that a data series is homogenous between two given times if $\mathrm{p}$-values are greater than the significance level, $\alpha(0.05)$. Pettit's (non-parametric) homogeneity test was utilized for the hydro-climatic data. The test was applied at $5 \%$ significance level. The result is presented in Tables 4 and 5 for monthly climatic and streamflow data respectively. 
Table 4: Results of Homogeneity Test for Precipitation, Maximum and Minimum Temperatures

\begin{tabular}{|l|l|l|l|l|}
\hline \multirow{2}{*}{ Station/Variable } & \multicolumn{2}{l|}{ Pettitt's Test } \\
\cline { 3 - 5 } & $\mathrm{U}$ & $\mathrm{p}$-value & Hypothesis \\
\hline \multirow{3}{*}{ Bauchi } & Precipitation & 5429 & 0.2664000 & $\mathrm{H}_{0}$ \\
\cline { 2 - 5 } & Maximum Temperature & 9339 & 0.0051330 & $\mathrm{Ha}$ \\
\cline { 2 - 5 } & Minimum Temperature & 13413 & 0.0000091 & $\mathrm{Ha}$ \\
\hline \multirow{3}{*}{ Hadejia } & Precipitation & 4884 & 0.3913000 & $\mathrm{H}_{0}$ \\
\cline { 2 - 5 } & Maximum Temperature & 6105 & 0.1563000 & $\mathrm{H}_{0}$ \\
\cline { 2 - 5 } & Minimum Temperature & 10243 & 0.0015300 & $\mathrm{Ha}$ \\
\hline \multirow{3}{*}{ Nguru } & Precipitation & 4319 & 0.5584000 & $\mathrm{H}_{0}$ \\
\cline { 2 - 5 } & Maximum Temperature & 6171 & 0.1479000 & $\mathrm{H}_{0}$ \\
\cline { 2 - 5 } & Minimum Temperature & 10851 & 0.0006362 & $\mathrm{Ha}$ \\
\cline { 2 - 5 } & Precipitation & 4875 & 0.4150000 & $\mathrm{H}_{0}$ \\
\cline { 2 - 5 } & Maximum Temperature & 5357 & 0.2809000 & $\mathrm{H}_{0}$ \\
\cline { 2 - 5 } & Minimum Temperature & 10902 & 0.0005897 & $\mathrm{Ha}$ \\
\hline
\end{tabular}

Table 5: Results of Homogeneity Test for Streamflow

\begin{tabular}{|l|l|l|l|}
\hline \multirow{2}{*}{ Gauge station } & \multicolumn{2}{|l|}{ Pettitt's Test } \\
\cline { 2 - 4 } & $\mathrm{U}$ & $\mathrm{p}$-value & Hypothesis \\
\hline Gashua & 6348 & 0.127 & $\mathrm{H}_{0}$ \\
\hline Hadejia & 24255 & $<2.2 \mathrm{e}-16$ & $\mathrm{Ha}$ \\
\hline Katagum & 2460 & 1.322 & $\mathrm{H}_{0}$ \\
\hline
\end{tabular}

From Table 4, occurrence of inhomogeneous series were detected among all stations; maximum and minimum temperatures of Bauchi station and minimum temperatures of all other stations. Thus, the p-values obtained were less than alpha, $\alpha$ at 0.05 significance level, thereby rejecting the null hypothesis of homogeneity. However, precipitation series of all the stations accepted the null hypothesis and were classified as homogeneous. Furthermore, results from Table 5 accepted the null hypothesis with the exception of Hadejia gauging station. Therefore, the inhomogeneous data series must be homogenized before further analysis.

The inhomogeneous hydro-climate data series were homogenized using the RHtestsV4 software. Thus, the homogenized data series accepted the null hypothesis (homogenous series) with the adjusted p-values.

\subsection{Autocorrelation Test}

Precipitation, maximum and minimum temperature series of the weather stations alongside streamflow series of the gauging stations having passed homogeneity test were next examined for the presence of first-order autocorrelation, AR(1). This is to ensure that the data series are drawn from independent series, and to determine whether pre-whitening is required. Tables 6 and 7 illustrates the results of the autocorrelation test conducted at $95 \%$ confidence interval using a twotailed test for climatic and streamflow data series respectively. The upper and lower limits of the confidence interval were calculated as +0.0908 and -0.0953 respectively. 
Table 6: Results of Autocorrelation Test for Climatic Data Series

\begin{tabular}{|l|l|l|}
\hline Station/Variable & $\mathrm{AR}(1), r_{1}$ \\
\hline \multirow{4}{*}{ Bauchi } & Precipitation & 0.686 \\
\cline { 2 - 3 } & Maximum Temperature & 0.607 \\
\cline { 2 - 3 } & Minimum Temperature & 0.710 \\
\hline \multirow{4}{*}{ Kano } & Precipitation & 0.620 \\
\cline { 2 - 3 } & Maximum Temperature & 0.535 \\
\cline { 2 - 3 } & Minimum Temperature & 0.736 \\
\hline \multirow{3}{*}{ Nguru } & Precipitation & 0.660 \\
\cline { 2 - 3 } & Maximum Temperature & 0.533 \\
\cline { 2 - 3 } & Minimum Temperature & 0.732 \\
\cline { 2 - 3 } & Precipitation & 0.598 \\
\cline { 2 - 3 } & Maximum Temperature & 0.554 \\
\cline { 2 - 3 } & Minimum Temperature & 0.743 \\
\hline
\end{tabular}

Table 7: Results of Autocorrelation Test for Streamflow Data Series

\begin{tabular}{|l|l|}
\hline Gauge station & $\mathrm{AR}(1), r_{1}$ \\
\hline Gashua & 0.680 \\
\hline Hadejia & 0.773 \\
\hline Katagum & 0.589 \\
\hline
\end{tabular}

All the data series evaluated reported the presence of positive lag-1 autocorrelation, as indicated in Tables 6 and 7 where $r_{1}$ values did not fell within the upper and lower limits of the confidence interval. Thus, this affirmed the importance of utilizing modified Mann-Kendall trend test to eliminate the autocorrelation using Trend Free Pre-Whitening approach (TFPW). Because the existence of positive autocorrelation increases the probability of rejecting the no-trend hypothesis, and may also cause trends to be detected that would not be found significant if the series were independent (no autocorrelation).

\subsection{Modified Mann-Kendall Trend Test and Sen's Slope Estimator}

The modified Mann-Kendall test (TFPW approach) was applied on the 37 years $(1980-2016)$ monthly and annual scales to detect trends in the hydro-climatic data series. More so, the magnitude of trends in the monthly and annual data series was determined using the Sen's slope estimator.

\subsubsection{Monthly Analysis of the Data Series}

The monthly precipitation, maximum and minimum temperature, and streamflow data series were analyzed for trend detection and the results presented in Tables 8 and 9. 
Table 8: MMK Test Results for Monthly precipitation, Maximum and Minimum Temperature

\begin{tabular}{|c|c|c|c|c|c|c|}
\hline \multirow{2}{*}{\multicolumn{2}{|c|}{ Station/Variable }} & \multicolumn{5}{|c|}{ MMK Trend Test } \\
\hline & & \multirow{2}{*}{$\begin{array}{l}\text { Kendall's tau } \\
0.0158\end{array}$} & \multirow{2}{*}{$\frac{p \text {-value }}{0.6199}$} & \multirow{2}{*}{$\begin{array}{l}\text { Sen's slope } \\
0.0000\end{array}$} & \multirow{2}{*}{$\begin{array}{l}\text { Alpha }(\alpha) \\
0.0500\end{array}$} & \multirow{2}{*}{$\begin{array}{l}\text { Interpretation } \\
\text { Accept } \mathrm{H}_{0}\end{array}$} \\
\hline Bauchi & Precipitation & & & & & \\
\hline & Maximum Temperature & 0.1375 & $1.54 \mathrm{e}-5$ & 0.0035 & 0.0500 & Reject $\mathrm{H}_{0}$ \\
\hline & Minimum Temperature & 0.1941 & $1.05 \mathrm{e}-9$ & 0.0045 & 0.0500 & Reject $\mathrm{H}_{0}$ \\
\hline \multirow[t]{3}{*}{ Hadejia } & Precipitation & 0.0132 & 0.6721 & 0.0000 & 0.0500 & Accept $\mathrm{H}_{0}$ \\
\hline & Maximum Temperature & 0.0527 & 0.0973 & 0.0017 & 0.0500 & Accept $\mathrm{H}_{0}$ \\
\hline & Minimum Temperature & 0.1325 & $3.10 \mathrm{e}-5$ & 0.0040 & 0.0500 & Reject $\mathrm{H}_{0}$ \\
\hline \multirow[t]{3}{*}{ Kano } & Precipitation & 0.0220 & 0.4823 & 0.0000 & 0.0500 & Accept $\mathrm{H}_{0}$ \\
\hline & Maximum Temperature & 0.0638 & 0.0448 & 0.0019 & 0.0500 & Reject $\mathrm{H}_{0}$ \\
\hline & Minimum Temperature & 0.1484 & $3.04 \mathrm{e}-6$ & 0.0041 & 0.0500 & Reject $\mathrm{H}_{0}$ \\
\hline \multirow[t]{3}{*}{ Nguru } & Precipitation & 0.0079 & 0.7985 & 0.0000 & 0.0500 & Accept $\mathrm{H}_{0}$ \\
\hline & Maximum Temperature & 0.0423 & 0.1836 & 0.0014 & 0.0500 & Accept $\mathrm{H}_{0}$ \\
\hline & Minimum Temperature & 0.1403 & $1.02 \mathrm{e}-5$ & 0.0046 & 0.0500 & Reject $\mathrm{H}_{0}$ \\
\hline
\end{tabular}

The results presented in Table 8 illustrates that monthly precipitation data series of all the stations accepted the null hypothesis of no trend. The Sen's slope estimates also indicated a zero value for all the stations. On the other hand, maximum and minimum temperature data series showed a mix of existence and non-existence of monotonic trend. Maximum temperature series of Bauchi and Kano stations indicated the existence of a positive trend with magnitudes $0.0035^{\circ} \mathrm{C}$ and $0.0019^{\circ} \mathrm{C}$ respectively. However, Hadejia and Nguru stations accepted the null hypothesis of no trend for the maximum temperature series. On the contrary, minimum temperature series of all the stations indicated the presence of positive trend with magnitudes $0.0045^{\circ} \mathrm{C}, 0.0040^{\circ} \mathrm{C}, 0.0041^{\circ} \mathrm{C}$ and $0.0046^{\circ} \mathrm{C}$ for Bauchi, Hadejia, Kano and Nguru stations respectively. The detected trends were all weak as indicated by Kendall's tau $(\tau)$ values less than 0.5 .

Table 9: MMK Test Results for Monthly Streamflow Data Series

\begin{tabular}{|l|l|l|l|l|l|}
\hline \multirow{2}{*}{ Gauge station } & \multicolumn{4}{|l|}{ MMK Trend Test } \\
\cline { 2 - 6 } & Kendall's tau $(\tau)$ & p-value & Sen's slope & Alpha $(\alpha)$ & Interpretation \\
\hline Gashua & 0.0082 & 0.7947 & 0.0000 & 0.0500 & Accept $\mathrm{H}_{0}$ \\
\hline Hadejia & -0.1639 & $2.51 \mathrm{e}-7$ & -0.0115 & 0.0500 & Reject $\mathrm{H}_{0}$ \\
\hline Katagum & 0.0012 & 0.9690 & 0.0000 & 0.0500 & Accept $\mathrm{H}_{0}$ \\
\hline
\end{tabular}

As indicated in Table 9, monthly streamflow series of Gashua and Katagum gauge stations accepted the null hypothesis of no trend with the exception of Hadejia gauge station. Hadejia station showed a decreasing trend with magnitude of $-0.0115 \mathrm{~m}^{3} / \mathrm{s} / \mathrm{month}$, and a negative tau value indicating a very weak trend.

\subsubsection{Annual Analysis of the Data Series}

Modified Mann-Kendall trend test was performed on mean annual precipitation, average annual maximum and minimum temperatures, annual average temperature, and mean annual streamflow data series for all the stations. The test statistics obtained from the trend test at $95 \%$ confidence level were presented in Tables 10 and 11 for mean annual precipitation; average annual maximum 
and minimum temperatures; annual average temperature, and mean annual streamflow respectively. Mean annual precipitation and streamflow were obtained by aggregating the monthly data series using Hydrognomon software. Unlike aggregation in precipitation and streamflow series, monthly temperature series were averaged to obtain the annual series. The annual average temperature was obtained by finding the average between the annual maximum and minimum temperature series for each station.

Table 10: MMK Test Result for the Mean Annual Precipitation Data Series

\begin{tabular}{|c|c|c|c|c|c|c|}
\hline \multirow{2}{*}{\multicolumn{2}{|c|}{ Station/Variable }} & \multicolumn{5}{|c|}{ MMK Trend Test } \\
\hline & & \multirow{2}{*}{$\begin{array}{l}\text { Kendall's tau } \\
0.3619\end{array}$} & \multirow{2}{*}{$\begin{array}{l}\text { p-value } \\
0.0020\end{array}$} & \multirow{2}{*}{$\begin{array}{l}\text { Sen's slope } \\
7.7960\end{array}$} & \multirow{2}{*}{$\begin{array}{l}\text { Alpha }(\alpha) \\
0.0500\end{array}$} & \multirow{2}{*}{$\begin{array}{l}\text { Interpretation } \\
\text { Reject } \mathrm{H}_{0}\end{array}$} \\
\hline Bauchi & MAP & & & & & \\
\hline & AATMax & 0.5111 & $1.23 \mathrm{e}-5$ & 0.0377 & 0.0500 & Reject $\mathrm{H}_{0}$ \\
\hline & AATMin & 0.6064 & $2.11 \mathrm{e}-7$ & 0.0535 & 0.0500 & Reject $\mathrm{H}_{0}$ \\
\hline & AAT & 0.5714 & $1.01 \mathrm{e}-6$ & 0.0487 & 0.0500 & Reject $\mathrm{H}_{0}$ \\
\hline \multirow[t]{4}{*}{ Hadejia } & MAP & 0.5048 & $1.58 \mathrm{e}-5$ & 8.1766 & 0.0500 & Reject $\mathrm{H}_{0}$ \\
\hline & AATMax & 0.3281 & 0.0057 & 0.0208 & 0.0500 & Reject $\mathrm{H}_{0}$ \\
\hline & AATMin & 0.4984 & $2.01 \mathrm{e}-5$ & 0.0445 & 0.0500 & Reject $\mathrm{H}_{0}$ \\
\hline & AAT & 0.5016 & $1.78 \mathrm{e}-5$ & 0.0444 & 0.0500 & Reject $\mathrm{H}_{0}$ \\
\hline \multirow[t]{4}{*}{ Kano } & MAP & 0.1968 & 0.0939 & 0.0000 & 0.0500 & Accept $\mathrm{H}_{0}$ \\
\hline & AATMax & 0.3460 & 0.0031 & 0.0275 & 0.0500 & Reject $\mathrm{H}_{0}$ \\
\hline & AATMin & 0.5683 & $1.16 \mathrm{e}-6$ & 0.0532 & 0.0500 & Reject $\mathrm{H}_{0}$ \\
\hline & AAT & 0.5397 & $3.88 \mathrm{e}-6$ & 0.0439 & 0.0500 & Reject $\mathrm{H}_{0}$ \\
\hline \multirow[t]{4}{*}{ Nguru } & MAP & 0.4032 & $5.69 \mathrm{e}-4$ & 5.7214 & 0.0500 & Reject $\mathrm{H}_{0}$ \\
\hline & AATMax & 0.2286 & 0.0514 & 0.0189 & 0.0500 & Reject $\mathrm{H}_{0}$ \\
\hline & AATMin & 0.6095 & $1.82 \mathrm{e}-7$ & 0.0597 & 0.0500 & Reject $\mathrm{H}_{0}$ \\
\hline & AAT & 0.5016 & $1.78 \mathrm{e}-5$ & 0.0453 & 0.0500 & Reject $\mathrm{H}_{0}$ \\
\hline
\end{tabular}

MAP=Mean Annual Precipitation, AATMax=Average Annual Maximum Temperature, AATMin=Average Annual Minimum Temperature, AAT=Average Temperature

Results of mean annual Precipitation (Table 10) indicated that; the null hypothesis, $\mathrm{H}_{0}$ was rejected for Bauchi, Hadejia and Nguru stations signifying positive trend with magnitude of $7.7960 \mathrm{~mm} / \mathrm{yr}$, $8.1766 \mathrm{~mm} / \mathrm{yr}$ and $5.7214 \mathrm{~mm} / \mathrm{yr}$ respectively. However, $\mathrm{H}_{0}$ was accepted for Kano station which indicates no trend present. A Kendall's tau $(\tau)$ value less than 0.5 indicates a weak trend; Bauchi and Nguru station's precipitation revealed a weak trend with the exception of Hadejia station. This was further supported by low coefficient of determination $\left(\mathrm{R}^{2}\right)$ values depicting 31.57 and $29.51 \%$ of variability in the mean annual precipitation of Bauchi and Nguru stations respectively (Figure 3).

More so, plots of mean annual precipitation, average annual maximum and minimum temperatures from 1980 to 2016 for all the stations were presented in Figures 3, 4 and 5 respectively. 

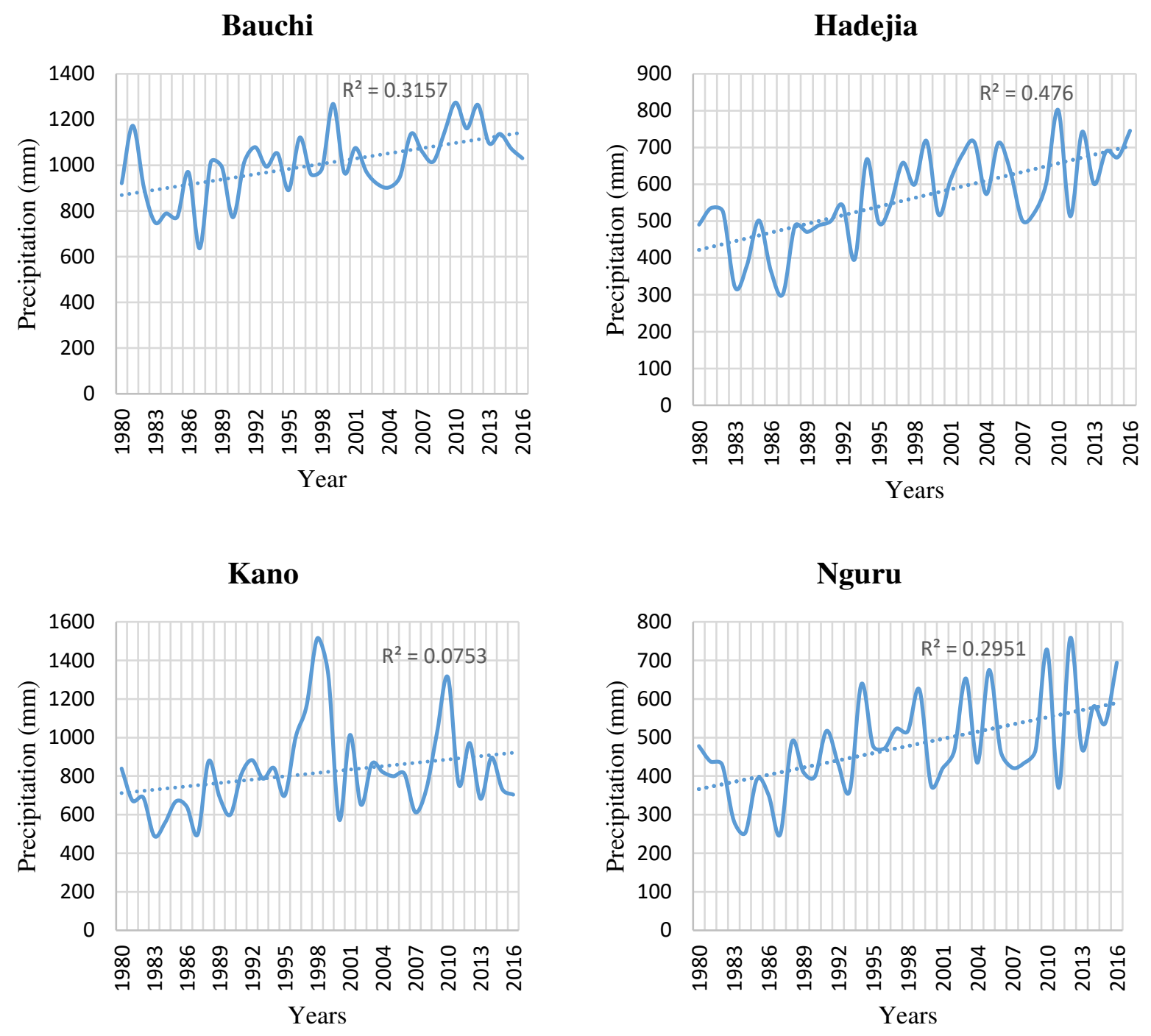

Figure 3: Plot of the Mean Annual Precipitation for the Stations 


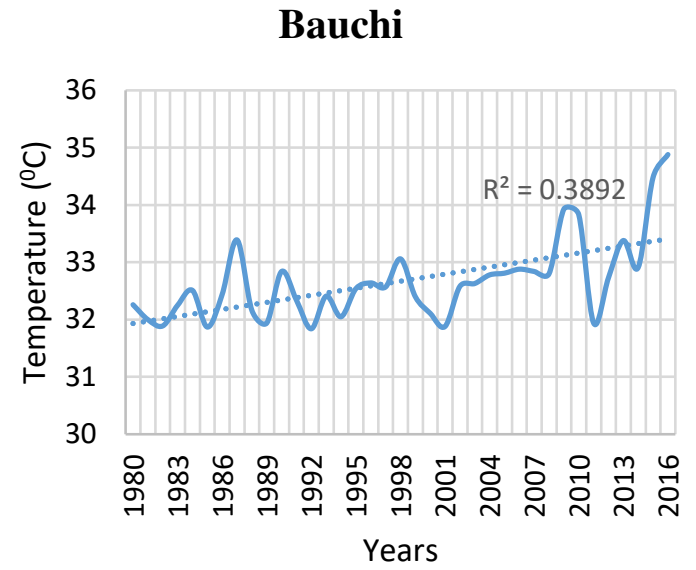

Kano

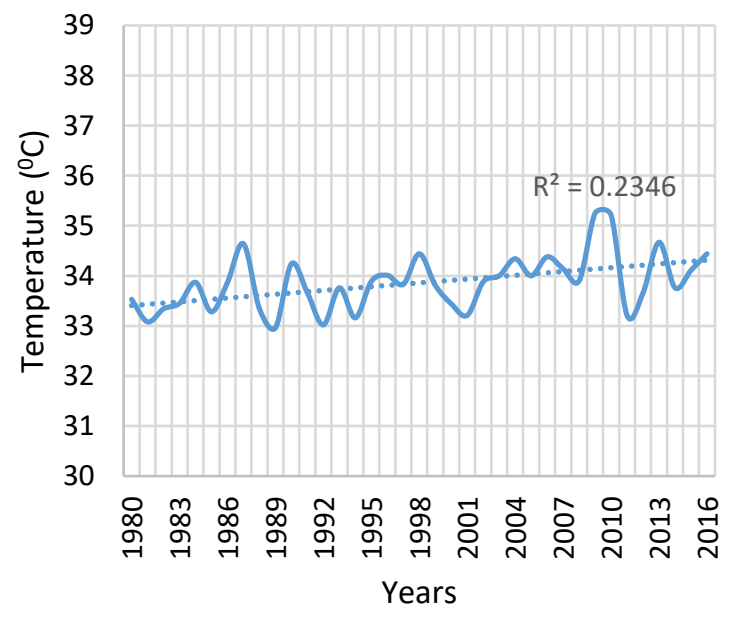

Hadejia

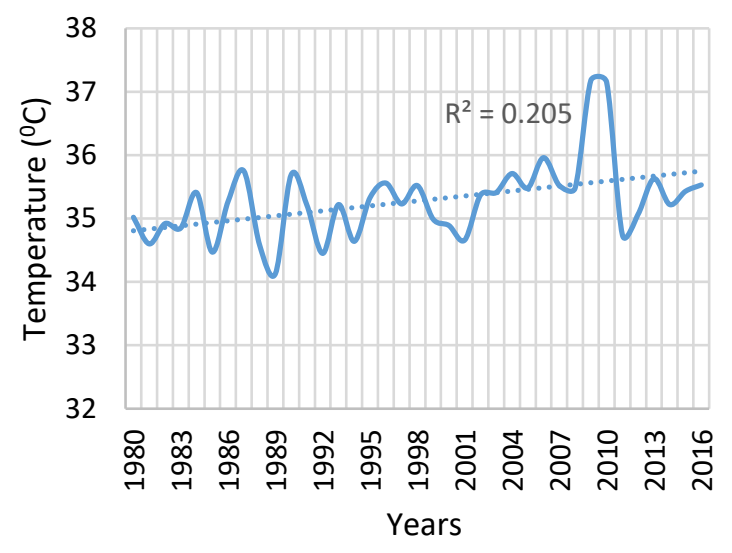

Nguru

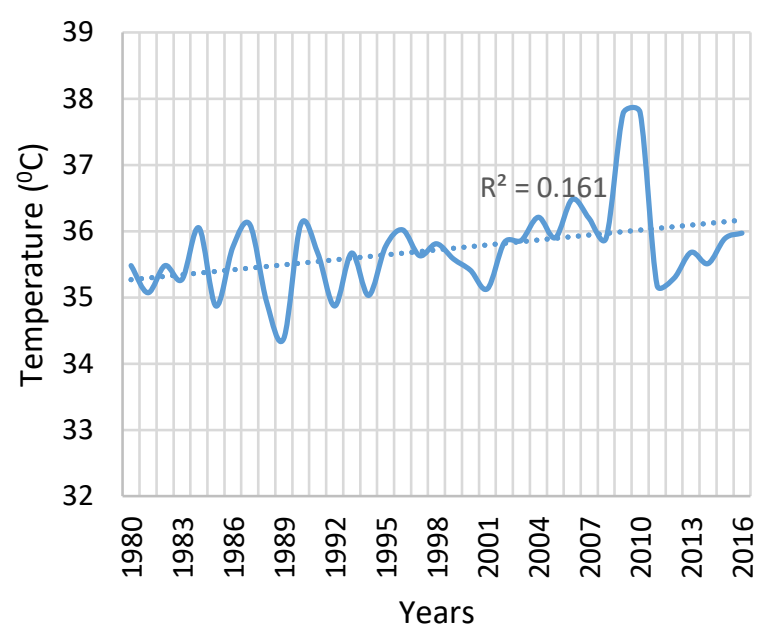

Figure 4: Plot of Average Maximum Temperature for the Stations 

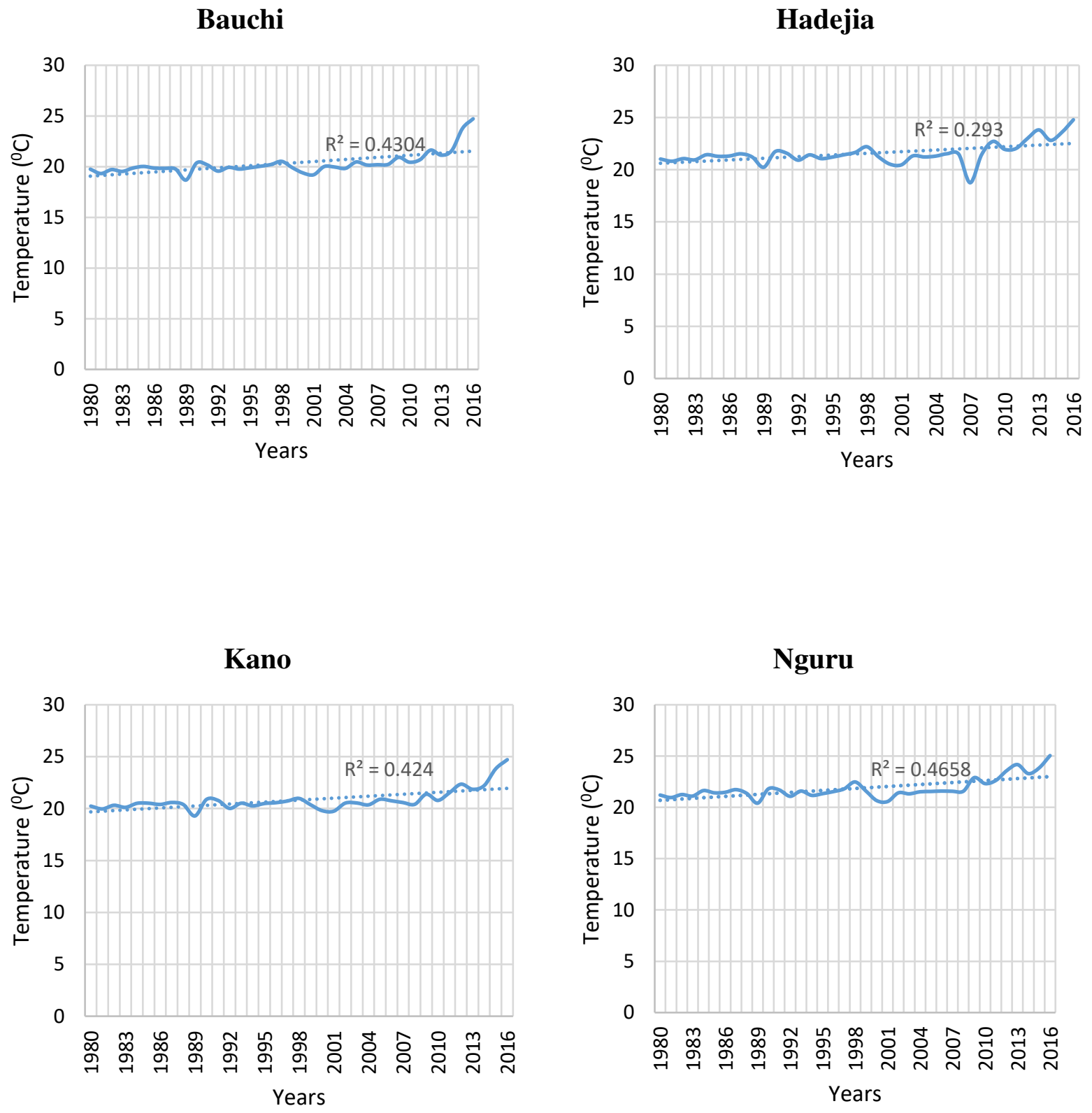

Figure 5: Plot of Average Minimum Temperature for the Stations

Likewise, result of average annual maximum and minimum temperatures (Table 10) indicated an existence of positive trend in the data series for all the stations. The Sen's slope suggested that average maximum and minimum temperatures at Bauchi, Hadejia, Kano and Nguru stations are increasing annually at a magnitude of $\left(0.0377^{\circ} \mathrm{C} 0.0208^{\circ} \mathrm{C}, 0.0275^{\circ} \mathrm{C}\right.$ and $\left.0.0189^{\circ} \mathrm{C}\right)$ and $\left(0.0535^{\circ} \mathrm{C}, 0.0445^{\circ} \mathrm{C}, 0.0532^{\circ} \mathrm{C}\right.$ and $\left.0.0597^{\circ} \mathrm{C}\right)$ per annum respectively. Furthermore, average annual maximum temperature series of all the stations displayed Kendall's tau $(\tau)$ values less than 
0.5 indicating a weak trend. This was further supported by the low $\mathrm{R}^{2}$ values presented in Figures 4 and 5. However, a strong trend was observed for all the station's minimum temperature series.

More so, result of annual average temperature (Table 10) depicted the presence of a positive trend. The magnitudes of the increasing trend suggested by the Sen's slope are $\left(0.0487^{\circ} \mathrm{C}, 0.0444^{0} \mathrm{C}\right.$, $0.0439^{\circ} \mathrm{C}$ and $0.0453^{\circ} \mathrm{C}$ ) per annum for Bauchi, Hadejia, Kano and Nguru station's respectively. This was in conformity with IPCC (2007) that "global temperature has been increasing since the 1980's".

The MMK trend test was also applied to the mean annual streamflow data series of Gashua, Hadejia and Katagum gauging stations. The results of which is presented in Table 11.

Table 11: MMK Test Results for Mean Annual Streamflow Data Series

\begin{tabular}{|l|l|l|l|l|l|}
\hline \multirow{2}{*}{$\begin{array}{l}\text { Gauge } \\
\text { station }\end{array}$} & \multicolumn{4}{|l|}{ MMK Trend Test } \\
\cline { 2 - 6 } & Kendall's Tau $(\tau)$ & $\mathrm{p}$-value & Sen's Slope & Alpha $(\alpha)$ & Interpretation \\
\hline Gashua & 0.1587 & 0.1775 & 0.0000 & 0.0500 & Accept $\mathrm{H}_{0}$ \\
\hline Hadejia & -0.3651 & 0.0018 & -3.7037 & 0.0500 & Reject $\mathrm{H}_{0}$ \\
\hline Katagum & 0.1968 & 0.0939 & 0.0000 & 0.0500 & Accept $\mathrm{H}_{0}$ \\
\hline
\end{tabular}

The results of the MMK trend test from Table 11 revealed that streamflow has a decreasing trend at Hadejia gauging station. The trend shows a negative change of $-3.7037 \mathrm{~m}^{3} / \mathrm{s} /$ year. However, no trend was detected for Gashua and Katagum gauging stations. This decrease in streamflow at Hadejia gauge station may be attributed to the combination of climate change and anthropogenic activities upstream of the gauge station. Anthropogenic activities such as reservoirs (Tiga and Challawa) and irrigation practices account for more of this reduction.

\section{Conclusion}

This study assessed the presence of trends in monthly and annual precipitation, maximum/minimum temperatures, and streamflow of Hadejia-Nguru Wetlands (HNWs) catchment over 37-year study period (1980-2016). The HNWs catchment lies between Bauchi, Hadejia, Kano and Nguru meteorological stations; and Gashua, Hadejia and Katagum streamflow gauge stations on Rivers Yobe, Hadejia and Jama'are respectively. Trends were detected using modified Mann-Kendall and Sen's slope estimator tests. The results of the study showed that all the stations have an increasing positive trends for monthly minimum, average annual minimum, average annual maximum, and annual average temperature data series. While monthly maximum temperature series of Bauchi and Kano stations indicated the presence of an increasing trend, and no trend was detected for Hadejia and Nguru stations. Furthermore, no trends was detected for monthly precipitation series at all stations. However, an increasing trend was detected at Bauchi, Hadejia and Nguru stations for mean annual precipitation. More so, a decreasing trend was detected for monthly and annual streamflow series at Hadejia gauge station; and no trend was detected for monthly and annual streamflow series at Gashua and Katagum gauge stations.

The trends detected for precipitation and temperature series were all in the positive direction, and associated with weather stations covering the HNWs, which may be related to strong changes in monthly and annual data in association with human activities; leading to climate change. Additionally, the decreased inflows at Hadejia gauge station on Hadejia River indicated evidence of anthropogenic activities upstream of the gauge station. Therefore, authorities should take proactive measures to mitigate the effect of climate change. The above findings will contribute to 
not only analyzing the trends in the hydrological time series, but also water resource planning and management in the semi-arid Hadejia Jama'are Komadugu Yobe Basin of Nigeria.

\section{Conflict of Interest}

No conflict of interest.

\section{Funding Statement}

No fund received to publish this manuscript.

\section{Author's Contribution}

S. Dan'azumi; Professor of Water Resources and Environmental Engineering at Bayero University Kano, Nigeria. He supervises Masters and $\mathrm{PhD}$ candidates in Water Resources and Environmental Engineering.

U. A. Ibrahim; a PhD candidate at Bayero University Kano under Prof. S. Dan'azumi's supervision. He drafted the manuscript as part of his $\mathrm{PhD}$ Thesis.

\section{Availability of Data and Material}

All data are available on request.

\section{Code Availability}

RStudio software was used, and the codes are available.

\section{Ethics Approval}

Non open access (if available); lack of funding.

\section{Consent to Participate}

If found worthy.

\section{Consent for Publication}

Full if accepted.

\section{References}

Ahmad, I., Tang, D., Wang, T., Wang, M. and Wagan, B. 2015. Precipitation Trends over Time Using Mann-Kendall and Spearman's rho Tests in Swat River Basin, Pakistan. Advances in Meteorology, 2015(2): 1-15.

Aich, V., Liersch, S., Vetter, T., Huang, S., Tecklenburg, J., Hoffmann, P., Koch, H., Fournet, S., Krysanova, V., Müller, E.N. and Hattermann, F.F. 2014. Comparing impacts of climate change on streamflow in four large African river basins. Hydrology and Earth System Science, 8: 1305-1321.

Ali, R., Kuriqi, A., Abubaker, S., and Kisi, O. 2019. Long-Term Trends and Seasonality Detection of the Observed Flow in Yangtze River Using Mann-Kendall and Sen's Innovative Trend Method. Water, 11(1855): 1-17.

Ayeni, A.O., Kapangaziwiri, E., Soneye, A.S.O. and Engelbrecht, F.A. 2015. Assessing the impact 
of global changes on the surface water resources of southwestern Nigeria. Hydrological Sciences Journal, 60(11): 1956-1971.

Ayeni, A.O., Ogunsesan, A.A. and Adekola, O.A. 2019. Provisioning ecosystem services provided by the Hadejia Nguru Wetlands, Nigeria - Current status and future priorities. Scientific African, 5: 1-13.

Burn, D.H. and Elnur, M.A.H. 2002. Detection of hydrologic trends and variability. Journal of Hydrology, 255: 107-122.

Chattopadhyay, S. and Edwards, D.R. 2016. Long-Term Trend Analysis of Precipitation and Air Temperature for Kentucky, United States. Climate, 4(10): 1-15.

Chattopadhyay, S., Edwards, D.R., Yu, Y. and Hamidisepehr, A. 2017. An Assessment of Climate Change Impacts on Future Water Availability and Droughts in the Kentucky River Basin. Environmental Process, 4(1): 1-31.

Chen, Y., Guan, Y., Shao, G. and Zhang, D. 2016. Investigating Trends in Streamflow and Precipitation in Huangfuchuan Basin with Wavelet Analysis and the Mann-Kendall Test. Water, 8(77): 1-32.

Chow, V.T, Maidment, D.R. and Mays, L.W. 1988. Applied Hydrology (2010 edn), Tata McGraw-Hill, New York, NY, USA: 572pp.

Dami, A., Kuchali, I.B. and Ayuba, H.K. 2017. The Influence of Climate Variability on HadejiaNguru Wetlands, Yobe State, Nigeria. International Journal of Geography and Geology, 6(5): $105-112$.

Drápela, K. and Drápelová, I. 2011. Application of Mann-Kendall test and the Sen's slope estimates for trend detection in deposition data from Bílý Křŕž (Beskydy Mts ., the Czech Republic) 1997 - 2010. Beskydy, 4(2): 133-146.

Droogers, P., Immerzeel, W.W., Terink, W., Hoogeveen, J., Bierkens, M.F.P., van Beek, L.P.H., and Debele, B. 2012. Water resources trends in Middle East and North Africa towards 2050. Hydrology and Earth System Science, 16: 3101-3114.

Ezemonye, M.N., Emeribe, C.N. and Anyadike, R.N.C. 2016. Estimating Stream Discharge of Aboine River Basin of Southeast Nigeria using Modified Thornthwaite Climatic Water Balance Model. Journal of Applied Sciences and Environmental Management, 20(3): 760768.

Gocic, M. and Trajkovic, S. 2013. Analysis of changes in meteorological variables using MannKendall and Sen's slope estimator statistical tests in Serbia. Global Planet Change, 100:172182.

Goes, B.J.M. 2001. Effects of damming the Hadejia River in semiarid northern Nigeria - lessons learnt for future management. In: Schumann, et al. (ed). Regional Management of Water Resources. Proceedings of a symposium held during the Sixth International Association of Hydrological Sciences, Scientific Assembly at Maastricht, The Netherlands, July 2001. IAHS Publication no. 268, 2001, pp. 73-80.

Hamed, K.H. 2008. Trend detection in hydrologic data: The Mann - Kendall trend test under the scaling hypothesis. Journal of Hydrology, 349: 350-363.

Hamed, K.H. and Rao, A.R.A. 1998. Modified Mann-Kendall trend test for autocorrelated data. Journal of Hydrology, 204: 182-196.

IPCC-Intergovernmental Panel on Climate Change. 2007. Climate Change 2007. The Physical Science Basis: Contribution of Working Group I to the Fourth Assessment Report of the Intergovernmental Panel on Climate Change. Full report. Cambridge, United Kingdom and New York, NY, USA: Cambridge University Press. 
IPCC-Intergovernmental Panel on Climate Change. 2013. Climate Change 2013: The Physical Science Basis. Contribution of Working Group I to the Fifth Assessment Report of the Intergovernmental Panel on Climate Change. (Stocker, T.F., D. Qin, G.-K. Plattner, M. Tignor, S.K. Allen, J. Boschung, A. Nauels, Y. Xia, Eds.). Cambridge, United Kingdom and New York, NY, USA: Cambridge University Press, 1535pp.

Kendall, M.G. 1975. Rank Correlation Methods (4th Ed.). Charles Griffin and Company, London, United Kingdom.

Kocsis, T., Kovács-Székely, I. and Anda, A. 2020. Homogeneity tests and non-parametric analyses of tendencies in precipitation time series in Keszthely, Western Hungary. Theoretical and Applied Climatology, 139: 849-859.

Kumar, S., Merwade, V., Kam, J. and Thurner, K. 2009. Streamflow trends in indiana: Effects of long term persistence, precipitation and subsurface drains. Journal of Hydrology, 374: 171183.

Mann, H.B. 1945. Nonparametric Tests against Trend. Econometrica: Journal of the Econometric Society, 13: 245-259.

NIMET-Nigerian Meteorolgical Agency. 2017. Nigerian Meteorolgical Agency; Drought and Flood Monitoring Bulletin. Abuja, Nigeria.

Okafor, G.C. and Ogbu, K.N. 2018. Assessment of the impact of climate change on the freshwater availability of Kaduna River basin, Nigeria. Journal of Water and Land Development, 38(1): 105-114.

Okali, D. and Bdliya, H. 1998. Guidelines for the Wise Use of the Hadejia-Nguru Wetlands. Hadejia-Nguru Wetlands Conservation Project/International Union for Conservation of Nature, Gland, Switzerland.

Olalekan, E.I., Abimbola, L.M., Saheed, M. and Damilola, O.A. 2014. Wetland Resources of Nigeria: Case Study of the Hadejia-Nguru Wetlands. Poultry, Fisheries and Wildlife Sciences, 2(2): 1-6.

Osuch, M. and Wawrzyniak, T. 2016. Climate projections in the Hornsund Area, Southern Spitsbergen. Polish Polar Research, 37(3): 379-402.

Partal, T. 2010. Wavelet transform-based analysis of periodicities and trends of Sakarya basin (Turkey) streamflow data. River Resources Applications, 26: 695-711.

Pettitt, A.N. 1979. A Non-parametric Approach to the Change-point Problem. Journal of Applied Statistics, 28(2): 126-135.

Shiru, M.S., Shahid, S., Alias, N. and Chung, E.S. 2018. Trend analysis of droughts during crop growing seasons of Nigeria. Sustainability, 10(871): 1-13.

Sonali, P. and Kumar, D.N. 2013. Review of Trend Detection Methods and their Application to Detect Temperature Changes in India. Journal of Hydrology, 476: 212-227.

Umar, A.S. and Ankidawa, B.A. 2016. Climate Variability and Basin Management: A Threat to and from Wetlands of Komadugu Yobe Basin, North Eastern Nigeria. Asian Journal of Engineering and Technology, 4(2): 25-36.

Umar, D.A., Ramli, F.M., Aris, Z.A., Jamil, N.R. and Abdulkareem, J.H. 2018. Runo ff irregularities, trends, and variations in tropical semi-arid river catchment. Journal of Hydrology: Regional Studies, 19: 335-348.

Wang, W., Chen, Y., Becker, S. and Liu, B. 2015. Variance Correction Prewhitening Method for Trend Detection in Autocorrelated Data. Journal of Hydrological Engineering, 20(12): 1-17.

WMO-World Meteorological Organisation. 2011. Guide to Climatological Practices (WMO/No 100). Geneva, Switzerland: World Meteorological Organisation. 
Yue, S., Pilon, P., Phinney, B. and Cavadias, G. 2002. The influence of autocorrelation on the ability to detect trend in hydrological series. Hydrological Processes, 16: 1807-1829.

Yue, S. and Wang, C.Y. 2004. The Mann-Kendall test modified by effective sample size to detect trend in serially correlated hydrological series. Water Resources Management, 18: 201-218. 